\title{
Biomarkery raka stercza
}

\author{
Aleksander Targoński, Andrzej Prajsner
}

Rak stercza jest drugim co do częstości nowotworem złośliwym u mężczyzn w Polsce. W diagnostyce tego nowotworu pomocne jest wykorzystanie różnych biomarkerów. Najbardziej popularnym i najlepiej poznanym wskaźnikiem jest PSA, który obok per rectum stanowi podstawowe badanie przesiewowe. Ocenie i interpretacji podlega stężenie całkowite PSA, stężenie frakcji wolnej oraz subfrakcji proPSA, a także zmiany stężenia PSA w czasie. U chorych ze zdiagnozowanym rakiem gruczołu krokowego wielu cennych informacji dostarcza analiza liczby krążących komórek nowotworowych (CTC). Ich stężenie rośnie w przypadku pojawienia się przerzutów. Wartość przekraczająca 5 CTC/7,5 ml krwi obwodowej wiąże się z niższą medianą przeżycia. Ponadto wyznaczenie profilu ekspresji genów CTC pozwala na przewidywanie lekowrażliwości komórek rakowych i indywidualny dobór terapii przeciwnowotworowej. Poza markerami osoczowymi wykorzystuje się również markery w moczu (m.in. PCA3) oraz markery komórkowe. Projektowane są pakiety łączące różne markery (np. PSA, CTC, albuminy i PSA), aby zwiększyć precyzję monitorowania przebiegu choroby i efektywność leczenia.

\section{Prostate cancer biomarkers}

Prostate cancer is the second most common cancer in men in Poland. Biomarkers are helpful in diagnosing of this neoplasm. The most popular and the best known biomarker in detecting of prostate cancer is PSA which serves as the essential diagnostic tool combined with digital rectal examination. Total PSA, free PSA, proPSA and fluctuations in tPSA levels in time can be measured. In patients with the established diagnosis of prostatic cancer circulating tumour, cells (CTCs) can be counted. Their concentration is increased in metastatic prostate cancer. CTCs level superior to $5 / 7.5 \mathrm{ml}$ is associated with poor survival. Molecular phenotyping of CTCs is useful in predicting drug sensitivity and in choosing the best individual therapeutic approach. Besides blood serum investigations there are also urinary and cellular (including genetic) biomarkers. To increase the accuracy of monitoring the treatment of the cancer, multiple biomarker panels are created e.g. PSA, CTCs, albumins and LDH.

Słowa kluczowe: biomarkery, PSA, krążące komórki nowotworowe, CTC

Key words: biomarkers, PSA, circulating tumor cells, CTC

NOWOTWORY Journal of Oncology 2014; 64, 3: 258-263

\section{Wstęp}

Jako że nowotwory złośliwe są drugą przyczyną zgonów w Polsce (powodując odpowiednio $26 \%$ i 23\% zgonów u mężczyzn i kobiet), a liczba zachorowań z tego powodu wzrosła u obu płci dwukrotnie na przestrzeni ostatnich trzech dekad, zagadnienie diagnostyki zwiększającej szanse wczesnego wykrywania nowotworów jest niezwykle ważne [1]. Wśród badań analitycznych stosowanych w diagnostyce chorób nowotworowych istotną rolę odgrywa wykorzystywanie biomarkerów. Marker biologiczny (biomarker) daje się obiektywnie zmierzyć i może być zastosowany w ocenie fizjologicznych procesów biologicznych, procesów patologicznych lub odpowiedzi organizmu na działania terapeutyczne [2]. Wyróżnia się następujące typy biomarkerów związanych z chorobami: a) diagnostyczne (diagnostic biomarkers) - informujące o potencjalnym istnieniu określonej choroby (np. czyn-

Kliniczny Oddział Urologii

Wydział Lekarski

Śląski Uniwersytet Medyczny w Katowicach 
Tabela I. Podział biomarkerów raka stercza

\begin{tabular}{ll}
\hline Biomarkery & $\begin{array}{l}\text { Biomarkery } \\
\text { zewnątrzkomórkowe }\end{array}$ \\
\hline We krwi: & - cytokeratyna \\
- PSA & - p63 \\
- CTC & - AMACR \\
- kalikreiny & - PSMA \\
- UPA & - Ki-67 \\
- TGF- $\beta$ 1 & - polimorfizm nukleotydowy \\
- interleukina 6 & - fuzje genowe \\
W moczu: & \\
- anneksyna 3 & \\
- metaloproteinazy macierzy & \\
- delta-katenina & \\
- czynnik wzrostu hepatocytów & \\
- tymozyna $\beta 15$ &
\end{tabular}

nik reumatoidalny w rozpoznawaniu reumatoidalnego zapalenia stawów),

b) rokownicze (prognostic biomarkers) — określające możliwy przebieg choroby u danego pacjenta niezależnie od podejmowania bądź niepodejmowania czynności leczniczych (np. obecność limfadenopatii u chorego $z$ rakiem nerki),

c) predykcyjne (predictive biomarkers) — związane z oceną odpowiedzi organizmu pacjenta na dane leczenie i wskazujące na prawdopodobieństwo wystąpienia określonego wyniku w zależności od podjęcia interwencji leczniczej (np. status hormonalny HER2/ER u pacjentek z rakiem sutka w kontekście planowanego leczenia trastuzumabem) [3-5].

\section{Biomarkery raka stercza}

Rak stercza u mężczyzn stanowi drugą przyczynę zachorowania po raku płuca, co stanowi 13,1\% ogółu zachorowań na nowotwory złośliwe i odpowiada standaryzowanemu współczynnikowi zachorowalności 32,3/100 000 [1]. Do biomarkerów raka gruczołu krokowego zalicza się [6]:

1. biomarkery zewnątrzkomórkowe:

a) we krwi: PSA, kalikreiny, UPA, TGF- $\beta$ 1, interleukina 6, CTC;

b) w moczu: PCA3, białka, DNA.

2. biomarkery wewnątrzkomórkowe: cytokeratyna, p63, AMACR, PSMA, Ki-67, polimorfizm nukleotydowy, fuzje genowe (tab. I).

\section{Zewnątrzkomórkowe biomarkery raka gruczołu krokowego PSA}

PSA (prostate specific antigen) jest proteazą serynową kalikreinopodobną, wytwarzaną przez komórki nabłonkowe gruczołu krokowego, której oznaczanie stężenia w surowicy należy, obok badania palpacyjnego per rectum oraz ultrasonografii przezodbytniczej, do podstawowych metod stosowanych przy wykrywaniu raka stercza. Większość PSA znajdującego się w surowicy połączona jest z nośnikami białkowymi: $\alpha 1$-antytrypsyną oraz $\alpha 2$-makroglobuliną, stanowiąc tzw. związane PSA (cPSA). Pozostała część to PSA wolne (fPSA), w skład którego wchodzą subfrakcje takie, jak: proPSA, intact PSA, nicked PSA i BPSA [6, 7]. Wprawdzie za punkt odniesienia dla prawidłowego wyniku badania stężenia tPSA w surowicy przyjmuje się $4 \mathrm{ng} / \mathrm{ml}$, to jednak należy uwzględnić wiek badanego. Wprowadzono zatem A-PSA (age-specific PSA reference range), obniżając wartość punktu odcięcia do $2,5 \mathrm{ng} / \mathrm{ml}$ dla mężczyzn poniżej 50 roku życia [8].

U mężczyzn z prawidłowym wynikiem badania palpacyjnego per rectum oraz stężeniem całkowitego PSA w surowicy w przedziale 4-10 ng/ml do różnicowania ryzyka wystąpienia raka stercza wykorzystywany jest stosunek wolnego do całkowitego PSA w surowicy (f/t PSA ratio). Na podstawie wyników biopsji stercza wykazano, że rak prostaty występował u 56\% chorych mających stosunek $\mathrm{f} / \mathrm{t}$ PSA $<0,1$ oraz u zaledwie $8 \%$ chorych $\mathrm{z}$ wynikiem f/t PSA > 0,25. Im niższa wartość ilorazu f/t PSA, tym większe prawdopodobieństwo istnienia raka stercza, choć przy interpretacji należy zachować ostrożność i wziąć pod uwagę dodatkowe czynniki laboratoryjne i kliniczne wpływające na wynik pomiaru, np. temperaturę przechowywania próbek czy wielkość gruczołu krokowego [6, 7]. Istnieją prace wskazujące na większą przydatność diagnostyczną obliczania stosunku proPSA (precursor isoforms of PSA) do fPSA niż ilorazu f/t PSA w wykrywaniu raka stercza [8], jednakże ta i inne molekularne formy PSA (BPSA-benign PSA, iPSA - intactPSA czy cPSA-complexPSA) mają ograniczone zastosowanie kliniczne [7]. U mężczyzn z negatywnym wynikiem badania per rectum oraz stężeniem tPSA 2-10 ng/ml wykazano bowiem, że stosunek proPSA/fPSA jest silniejszym wskaźnikiem wystąpienia raka (czułość 38,8\%, swoistość 90\%) niż oznaczenie tPSA (czułość 5,1\%), f/tPSA (czułość 20\%) oraz gęstości PSA (PSAD — PSA density), rozumianej jako stężenie tPSA w przeliczeniu na jednostkę objętości gruczołu (czułość 26,5\%) [9].

Wprowadzono także do użytku wskaźniki dynamiczne, odzwierciedlające zmianę stężenia PSA w czasie: szybkość narastania PSA (PSAV — PSA velocity) oraz czas podwojenia PSA (PSADT — PSA doubling time). Ich znaczenie diagnostyczne jest ograniczone, ale mogą być one stosowane jako biomarkery rokownicze u pacjentów leczonych z powodu raka prostaty. Nie wykazano ich przewagi w stosunku do pomiaru stężenia PSA całkowitego w surowicy [7].

\section{Krążące komórki nowotworowe}

Za kolejny biomarker raka gruczołu krokowego uznać należy krążące komórki nowotworowe (CTC — circulating tumour cells).

Pierwsze udokumentowane wzmianki o krążących komórkach nowotworowych pochodzą z 1869 r. Są one 
komórkami swobodnie przemieszczającymi się we krwi i pochodzącymi z pierwotnego ogniska guza lub z jego przerzutów. Przechodzą przemianę fenotypową ułatwiającą ich migrację (EMT - epithelial-mesenchymal transition), m. in. poprzez zmniejszenie ekspresji E-kadheryny, wzrost aktywności metaloproteinaz oraz syntezę integryn. Dostają się do układu krążenia przez naczynia krwionośne powstałe w toku neoangiogenezy lub też przez naczynia już istniejące [10]. Są zdolne do inicjowania powstawania przerzutów odległych, ale mogą też powodować wstecznie tworzenie nowych zmian w narządzie, w którym guz stał się źródłem ich rozsiewu w organizmie, prawdopodobnie na drodze procesów odwrotnych do wcześniej opisywanych (MET - mesenchymal-epithelial transition) $[10,11]$.

Liczbę krążących komórek nowotworowych we krwi w stosunku do pozostałych elementów morfotycznych szacuje się na około 1:109 . W pobranej próbce krwi CTC wychwytywane są przy pomocy przeciwciał skierowanych wobec białek adhezyjnych EpCAM (epithelial cell adhesion molecule). Następnie komórki selekcjonuje się tak, aby wykazywały dodatnią reakcję na cytokeratyny $(\mathrm{CK}-6,8,18)$, dodatnią reakcję na 4,6-diamino-2-fenylindol (potwierdzenie obecności jądra komórkowego) oraz ujemną reakcję na CD45 (wykluczenie leukocytów). Wybrane według powyższego klucza komórki są ostatecznie sprawdzane i klasyfikowane przez badacza jako CTC, a ich liczbę podaje się w przeliczeniu na 7,5 ml pobranej krwi żylnej. Ich dalsza analiza i określanie profilu genetycznego odbywa się z wykorzystaniem technik cytometrii przepływowej oraz łańcuchowej reakcji polimerazy z odwrotną transkryptazą na matrycy mRNA $[10,11]$.

W raku stercza krążące komórki nowotworowe dzielone są na dwa typy: pierwotne, wykrywane na etapie diagnostyki, oraz wtórne, pojawiające się po leczeniu radykalnym. Wykazano, że pacjenci, u których nie stwierdza się pierwotnych CTC, obarczeni są niższym ryzykiem wystąpienia mikroprzerzutów. Ponadto ekspresja tetraspaniny CD82 w pierwotnych CTC wiąże się z mniejszym stopniem zaawansowania guza oraz niższym prawdopodobieństwem wystąpienia mikroprzerzutów do kości [12].

CTC u chorych na raka stercza wykazują ekspresję PSA i AMACR ( $\alpha$-methylacyl-CoA racemase) oraz mogą posiadać typowe dla tkanki raka prostaty mutacje receptora androgenowego i białka PTEN (phosphatase and tensin homolog deleted on chromosome ten) czy też fuzje genowe, np. TMRPSS:ETV $[5,11]$.

Rak stercza może dawać przerzuty do kości, przy czym zdarzają się one rzadko w nowo rozpoznanym guzie, a częściej (do 65\%) w przypadku guza hormonoopornego. Powstawanie przerzutów do tkanki kostnej zachodzi za pośrednictwem CTC, które przyjmują we krwi dwie postacie: małych komórek nabłonkowych (CECs - cancer epithelial cells) oraz dużych komórek łączących się w skupiska (CCCs
- cancer cell clusters), przy czym te drugie występują liczniej. Dla obydwu postaci wykazano istnienie wzorca fenotypowego, który koreluje z istnieniem przerzutów raka stercza. Polega on na zwiększeniu ekspresji genów kodujących GPX1, SOD2, receptor androgenowy AR, cyklinę $B$ oraz bFGF. Największą czułością cechują się GPX1 (97\%) oraz SOD2 (89\%). Ponadto nadekspresja genów kodujących AR, bFGF i cykliny B wiąże się z opornością na leczenie hormonalne [13]. Wykazano korelację pomiędzy liczbą krążących komórek nowotworowych we krwi a medianą przeżycia pacjentów z rakiem stercza: poziom CTC $\geq 5 / 7,5 \mathrm{ml}$ wiązał się z istotnie mniejszą medianą przeżycia niż poziom CTC $<5 / 7,5 \mathrm{ml}$ [5]. We wczesnych stadiach guza liczba CTC jest mniejsza niż u chorych z istniejącymi przerzutami [14]. Przyjmuje się różne punkty odniesienia dla odróżnienia miejscowego raka stercza od raka stercza z przerzutami i wahają się one pomiędzy 2 a 5 CTC w przeliczeniu na 7,5 ml krwi obwodowej [15]. Stwierdzono również, że w przypadku raka stercza z przerzutami obok wzrostu liczby krążących komórek nowotworowych zwiększa się także ilość mRNA kodującego AGR2 (anterior gradient 2) - białka należącego do rodziny izomeraz dwusiarczkowych. Marker ten koreluje ze zwiększonym stężeniem chromograniny A i swoistej enolazy neuronowej w surowicy u pacjentów z neuroendokrynnym typem raka stercza z przerzutami. Osoczowe stężenie AGR2 może posłużyć do doboru i monitorowania leczenia pacjentów z rozsianym rakiem stercza [16].

CTC mogą stanowić czynnik prognostyczny u pacjentów z hormonoopornym rakiem stercza (CRPC - castration resistant prostate cancer) i lepiej niż PSA odzwierciedlać odpowiedź na leczenie. Im więcej CTC, tym gorsze przeżycie całkowite u pacjentów z hormonoopornym rakiem stercza $[10,17]$.

Ustalenie profilu ekspresji wybranych genów CTC (m.in. receptora androgenowego, cykliny B oraz beta FGF) dla nowotworu u danego pacjenta, zwane „płynną biopsją stercza”, jest punktem wyjścia dla indywidualnego doboru schematu leczenia (w tym chemioterapii), oceny jego skuteczności oraz określenia przyczyn lekooporności. Oznaczenie stężenia CTC w okresie przed leczeniem pierwotnym i po nim może stanowić wskazówkę co do wyboru terapii adiuwantowej. W przypadku pacjentów leczonych hormonoterapią rozsiew procesu nowotworowego może być wychwycony w oparciu o wzrost liczby CTC jeszcze wówczas, gdy stężenie PSA pozostaje na niewykrywalnie niskim poziomie.

Proponuje się także utworzenie „pakietu biomarkerów”, które wskazywałyby na obecność krążących komórek nowotworowych, np. LDH, albuminy, PSA oraz CTC, które miałyby odzwierciedlać prawdopodobieństwo wystąpienia określonego punktu końcowego w leczeniu raka stercza u konkretnego chorego $[5,13,18,19]$.

Prowadzono również badania nad komórkami podobnymi do fibroblastów (fibroblast-like cells), o profilu nieco 
odmiennym od CTC, tj. CK (-), DAPI (+), CD 45 (-) i wimentyna (+), których obecność we krwi obwodowej mogłaby odróżniać raka stercza z przerzutami od raka stercza ograniczonego do narządu [20].

\section{Inne biomarkery zewnątrzkomórkowe we krwi}

Wśród pozostałych markerów osoczowych użytecznych w diagnostyce raka gruczołu krokowego znajdują się $\mathrm{m}$. in.: kalikreiny, UPA, TGF- $\beta$ 1, interleukina 6.

Kalikreiny są kodowane przez 15 genów znajdujących się w locus KLK na chromosomie 19q13-4. Należy do nich m. in. kalikreina 2 (hK2 - human kallikrein type 2), ulegająca nadekspresji u pacjentów z rakiem prostaty. Jako biomarker służy stosunek mRNA hK2:PSA, który, jak wykazano, rośnie wraz ze wzrostem stopnia zaawansowania guza.

Prowadzone są także badania nad urokinazowym aktywatorem plazminogenu (UPA — urokinase plasminogen activator), biorącym udział w karcynogenezie i powstawaniu przerzutów raka stercza. Zarówno UPA, jak i jego inhibitor PAl-1 wykazują zwiększoną ekspresję u pacjentów ze wznową procesu nowotworowego.

Markerem zewnątrzkomórkowym dla raka prostaty jest również czynnik wzrostu TGF $\beta$ 1, wykazujący dodatnią korelację ze stopniem zaawansowania guza i obecnością przerzutów.

Podobnie zwiększona ekspresja interleukiny $\mathbf{6}$ oraz jej receptora u pacjentów z rakiem stercza koreluje $z$ istnieniem przerzutów, a ponadto wiąże się z hormonoopornością guza [5]. Także niekodujące fragmenty RNA o długości 21-23 par nukleotydów znajdujące się w surowicy (tzw. miCroRNA), wpływające na regulację translacji odpowiednich sekwencji mRNA, mogą mieć znaczenie jako biomarkery raka stercza [21, 22].

\section{Biomarkery zewnątrzkomórkowe w moczu}

Niektóre z biomarkerów zewnątrzkomórkowych mogą być monitorowane w oparciu o analizę moczu. PCA3 (prostate cancer antigene 3) jest genem, którego transkrypt stanowi niekodujące RNA, wykrywane w podwyższonych stężeniach w moczu pacjentów z rakiem stercza, mierzone zarówno w sposób izolowany, jak również w odniesieniu do stężenia mRNA genu kodującego PSA.

W moczu chorych na raka prostaty stwierdza się również zmianę ilości takich białek, jak: anneksyna 3, metaloproteinazy macierzy, delta-katenina, czynnik wzrostu hepatocytów i tymozyna $\beta 15$. Trwają badania mające ugruntować ich rolę jako biomarkerów [21, 22].

\section{Wewnątrzkomórkowe biomarkery raka gruczołu krokowego}

Poza badaniem płynów ustrojowych takich jak krew i mocz możliwe jest wykorzystanie jako biomarkerów związków znajdujących się w przestrzeni wewnątrzkomórkowej.
Cytokeratyna wielkocząsteczkowa oraz białko p63 są składnikami komórek warstwy podstawnej nabłonka gruczołowego stercza, które można uwidocznić przy użyciu specyficznych przeciwciał. Gruczolakorak stercza pozbawiony jest tej warstwy komórek i wynik reakcji barwnej będzie negatywny [6]. Marker ten nie jest jednak specyficzny i negatywny wynik testu opisywany był również w przypadku zmian łagodnych, związanych z częściową atrofią stercza [22].

Kolejnym markerem komórkowym raka prostaty jest AMACR ( $\alpha$-methylacyl-CoA racemase), którego wykrywanie może być wykorzystywane przy badaniu bioptatów z niewielkimi i trudnymi do znalezienia ogniskami atypii. Specyficzność tego markera jest jednakowoż niska — dodatnią reakcję można uzyskać u pacjentów z rakiem stercza, ale również z łagodnym rozrostem stercza i PIN (prostatic intraepithelial neoplasia) [6, 22].

PSMA (prostate-specific membrane antigen) jest białkiem błony komórkowej, którego nadekspresja jest skorelowana ze stopniem zaawansowania raka stercza, wzrostem guza niezależnym od regulacji androgenowej, obecnością przerzutów oraz wznową biochemiczną [6].

Do markerów komórkowych zalicza się też antygen Ki-67. W czasie interfazy można wykazać jego obecność w jądrze komórkowym, szczególnie w jąderkach. W czasie mitozy Ki-67 stwierdzany jest na powierzchni chromosomów, jest jednym z białek wchodzących w skład warstwy perichromosomalnej. Ki-67 jest obecny w komórce podczas wszystkich faz czynnych cyklu komórkowego (G1, S, G2 i mitoza) i niewykrywalny w fazie G0. Jest on uważany za dobry wskaźnik indeksu mitotycznego komórek i frakcji dzielących się komórek oraz ma znaczenie rokownicze u pacjentów po radykalnej prostatektomii, radioterapii lub kastracji farmakologicznej [6, 22].

Kluczową rolę w patogenezie progresji raka stercza odgrywa receptor androgenowy (AR - androgen receptor). Wykazano, że zwiększona ekspresja AR w jądrze komórkowym w tkance stercza pochodzącej z bioptatów bądź z preparatu po prostatektomii wiązała się z większą śmiertelnością pacjentów z rakiem stercza. Trwają badania nad udziałem HER2 (human epidermal growth factor receptor 2) w patogenezie raka prostaty [22].

Do biomarkerów komórkowych o zwiększonej ekspresji u pacjentów z rakiem stercza należą też białka: TATI (tumour-associated trypsin inhibitor) oraz PSP94 (prostate specific protein of 94 aminoacids). Ten ostatni, określany też mianem MSMB, jest niezależnym markerem prognostycznym wznowy po prostatektomii [22].

Białka szoku cieplnego (HSP - heat shock proteins) także wykazują wzrost ekpresji w komórkach raka stercza. Stężenie HSP60 wykorzystywane jest do wykrywania wznowy biochemicznej po radykalnej prostatektomii, natomiast HSP90 bierze udział w rozwoju raka przez interakcję z AR i może mieć znaczenie jako punkt uchwytu leków [22]. 
Do markerów wewnątrzkomórkowych należą ponadto zmiany wykrywane na poziomie materiału genetycznego. Utrata ramienia krótkiego oraz dodanie ramienia długiego chromosomu 8. należą do najczęstszych aberracji w raku stercza. Zależny od androgenów czynnik regulujący transkrypcję NKX3.1 ma charakter supresorowy i zmniejszenie jego ekspresji wiąże się z wyższym ryzykiem transformacji nowotworowej [22].

Bogatym źródłem wiedzy są polimorfizmy nukleotydowe. Zidentyfikowano 35 polimorfizmów pojedynczych nukleotydów powiązanych z rakiem stercza, które odpowiadają w $20 \%$ za ryzyko rodzinnego występowania choroby. Nie wykazano jednak korelacji pomiędzy obecnością polimorfizmu a stadium zaawansowania raka prostaty. Występowanie dwóch z opisywanych polimorfizmów, tj. rs10993994 oraz rs5945619, jest skorelowane dodatnio z wysokością punktacji w skali Gleasona [6].

Wśród fuzji genowych spotykanych w raku stercza najlepiej przebadaną jest ta dotycząca genu kodującego białko TMPRSS2 (prostate-specific gene transmembrane protease serine 2) z genem kodującym białka ETS (erythroblastosis virus E26 transforming sequence). Udział białka TMPRSS2 w karcynogenezie jest zależny od nadekspresji genu kodującego czynniki transkrypcyjne z rodziny ETS, w tym ERG i ETV1. Fuzja TMPRSS2:ETV1 jest rzadsza i dotyczy 1-10\% przypadków raka prostaty, podczas gdy fuzja TMPRSS:ERG występuje z częstością 40-80\%. Odpowiada ona za zakłócenie ścieżki sygnałowej receptora androgenowego i uniezależnienie tkanki nowotworowej od działania androgenów [5].

Delecja w obrębie genu kodującego białko PTEN (phosphatase and tensin homologue protein) występuje częściej u pacjentów z rakiem stercza dającym przerzuty niż z rakiem stercza ograniczonym do narządu. Delecja ta prowadzi do aktywacji ścieżki sygnałowej PI3K (phosphatidylinositol 3-kinase) i koreluje z wyższym stopniem zaawansowania guza, wyższą punktacją w skali Gleasona oraz z rozwojem hormonooporności [21].

W odniesieniu do wielu nowotworów złośliwych, w tym również raka prostaty, wykazano mutację genu supresorowego p53, którego ekspresja może mieć znaczenie rokownicze u pacjentów z rakiem stercza w trakcie terapii [22].

\section{Podsumowanie}

Dynamiczny rozwój badań molekularnych, w tym ciągłe odkrywanie biomarkerów, jest nieocenionym sprzymierzeńcem pacjentów w walce z rakiem stercza, a zarazem źródłem wiedzy o chorobie dla opiekujących się nimi lekarzy specjalistów. Biomarkery wykorzystywane są w celu postawienia właściwego rozpoznania choroby, oceny prawdopodobień- stwa wystąpienia określonych skutków klinicznych, oceny szans na uzyskanie odpowiedzi na zastosowane leczenie, oszacowania efektów fizjologicznych stosowanego leczenia, oceny wpływu terapii na czas przeżycia pacjenta oraz definiowania biologicznych wyznaczników nieskuteczności terapii lub progresji choroby.

U chorych na raka stercza analizie mogą być poddawane zarówno biomarkery zewnątrzkomórkowe (obecne we krwi lub w moczu), jak i wewnątrzkomórkowe (będące białkami strukturalnymi lub nośnikami informacji genetycznej).

Na wczesnym etapie diagnostyki, tj. w fazie wykrywania raka gruczołu krokowego, źródłem informacji są: stężenie całkowitego (tPSA) oraz wolnego PSA (fPSA) w surowicy, stosunek stężenia wolnego do całkowitego PSA oraz stosunek stężenia subfrakcji proPSA do wolnego PSA, stężenie pierwotnych krążących komórek nowotworowych we krwi, nadekspresja kalikreiny 2, obecność micro-RNA, stężenie PCA3 w moczu, brak reakcji immunohistochemicznej dla cytokeratyny wielkocząsteczkowej oraz białka p63 (w bioptatach stercza), nadekspresja PSMA, utrata ramienia krótkiego oraz dodanie ramienia długiego chromosomu 8.

U pacjentów z rozpoznaniem raka stercza zastosowanie mogą mieć biomarkery służące sprawdzeniu reakcji na wdrożone leczenie oraz informujące o ewentualnej progresji choroby. Wymienić tu należy szybkość narastania PSA (PSAV), czas podwojenia PSA (PSADT), stężenie wtórnych krążących komórek nowotworowych, markery oporności na leczenie hormonalne: nadekspresję genów AR, bFGF i cykliny B w CTC, delecję w obrębie genu kodującego białko PTEN, fuzję genową TMPRSS:ERG, markery wznowy po leczeniu radykalnym: stężenie urokinazowego aktywatora plazminogenu i jego inhibitora PAl-1 oraz stężenie białek MSMB i HSP60.

Można oszacować ryzyko wystąpienia przerzutów raka prostaty dzięki takim biomarkerom, jak: stężenie pierwotnych CTC, nadekspresja tetraspaniny CD82, zwiększenie ekspresji genów kodujących GPX1, SOD2, receptor androgenowy AR, cyklinę $B$ oraz bFGF w krążących komórkach nowotworowych, ilość mRNA kodującego AGR2, ilość komórek podobnych do fibroblastów (fibroblast-like cells) o profilu [CK (-), DAPI (+), CD 45 (-), wimentyna (+)] w surowicy, nadekspresja TGF beta-1 oraz interleukiny 6 .

Istnieją także markery pomocne w ocenie czasu przeżycia i rokowania chorego z zaawansowanym rakiem stercza. Należą do nich m.in.: poziom CTC $\geq 5 / 7,5 \mathrm{ml}$, stężenie antygenu Ki-67 i poziom ekspresji receptora androgenowego w jądrze komórkowym.

Zastosowanie biomarkerów w diagnostyce i terapii raka stercza jest dziedziną otwartą i wymagającą ciągłych naukowych dociekań w poszukiwaniu jak najlepszej czułości 
i specyficzności, a jednocześnie coraz bardziej potrzebną i stwarzającą obiecujące perspektywy.

\section{Lek. Aleksander Targoński}

Kliniczny Oddział Urologii

Wojewódzki Szpital Specjalistyczny nr 5

im. św. Barbary w Sosnowcu

Plac Medyków 1, 41-219 Sosnowiec

e-mail:aleksander.targonski@gmail.com

Otrzymano: 20 sierpnia $2013 \mathrm{r}$.

Przyjęto do druku: 25 lutego 2014 r.

\section{Piśmiennictwo}

1. Wojciechowska U, Didkowska J, Zatoński W. Nowotwory złośliwe w Polsce w 2010 roku. Warszawa: Centrum Onkologii — Instytut im. Marii Skłodowskiej-Curie, 2012.

2. Śpiewak M, Kruk M. Biomarkery w ostrych zespołach wieńcowych. Post Kardiol Interw 2008; 14: 183-187.

3. Gosho M, Nagashima K, Sato Y. Study designs and statistical analyses for biomarker research. Sensors 2012; 12: 8966-8986.

4. Buyse M, Sargent DJ, Grothey A i wsp. Biomarkers and surrogate end points-the challenge of statistical validation. Nat Rev Clin Oncol 2010; 7: 309-317.

5. Danila DC, Fleisher M, Scher HI. Circulating tumor cells as biomarkers in prostate cancer. Clin Cancer Res 2011; 17: 3903-3912.

6. ArtibaniW. Landmarks in prostate cancer diagnosis: the biomarkers. $B J U$ International 2012; 110 (Suppl. 1): 8-13.

7. Heidenreich A, Bastian PJ, Bellmunt J i wsp. Guidelines on prostate cancer. European Association of Urology 2013 (http://www.uroweb. org).

8. Richardson TD, Oesterling JE. Age-specific reference ranges for serum prostate-specific antigen. Urol North Am 1997; 24: 339-351.

9. Guazzoni G, Nava L, Lazzeri M i wsp. Prostate-specific antigen (PSA) isoform p2PSA significantly improves the prediction of prostate cancer at initial extended prostate biopsies in patients with total PSA between 2.0 and $10 \mathrm{ng} / \mathrm{ml}$ : results of a prospective study in a clinical setting. Eur Urol 2011; 60: 214-222.

10. Dotan E, Cohen SJ, Alpaugh KR i wsp. Circulating tumor cells: evolving evidence and future challenges. The Oncologist 2009; 14: 1070-1082.

11. Sun YF, Yang XR, Zhou J i wsp. Circulating tumor cells: advances in detection methods, biological issues, and clinical relevance. $J$ Cancer Res Clin Oncol 2011; 137: 1151-1173.

12. Murray NP, Reyes E, Badínez L i wsp. Detection and characteristics of primary circulating prostate cells; association with micrometastasis and implications for surgical treatment of men with prostate cancer. Arch Esp Urol 2010; 63: 345-353.

13. Giesing M, Driesel G, Molitor Di wsp. Molecular phenotyping of circulating tumour cells in patients with prostate cancer: prediction of distant metastases. BJU International 2012; 110: 1202-1211.

14. Maestro LM, Sastre J, Rafael SB i wsp. Circulating tumor cells in solid tumor in metastatic and localized stages. Anticancer Res 2009; 29: 4839-4843.

15. Folkersma LR, Manso LSJ, Romo IG i wsp. Prognostic significance of circulating tumor cell count in patients with metastatic hormone-sensitive prostate cancer. Urology 2012; 80: 1328-1332.

16. Kani K, Malihi PD, Jiang Y i wsp. Anterior gradient 2 (AGR2): blood-based biomarker elevated in metastatic prostate cancer associated with the neuroendocrine phenotype. The Prostate 2013; 73: 306-315.

17. De Bono JS, Scher HI, Montgomery RB i wsp. Circulating tumor cells predict survival benefit from treatment in metastatic castration-resistant prostate cancer. Clin Cancer Res 2008; 14: 6302-6309.

18. RiethdorfS, Pantel K. Advancing personalized cancer therapy by detection and characterization of circulating carcinoma cells. Ann N Y Acad Sci 2010; 1210: 66-77.

19. Danila D, Pantel K, Fleisher Mi wsp. Circulating tumors cells as biomarkers: progress toward biomarker qualification. Cancer J 2011; 17: 438-450.

20. Jones ML, Siddiqui J, Pienta KJ i wsp. Circulating fibroblast-like cells in men with metastatic prostate cancer. The Prostate 2013; 73: 176-181.

21. Schwarzenbach $\mathrm{H}$, Alix-Panabières $\mathrm{C}$, Müller I. Cell-free tumor DNA in blood plasma as a marker for circulating tumor cells in prostate cancer. Clin Cancer Res 2009; 15: 1032-1038.

22. Bjartell A, Montironi R, Berney D i wsp. Tumour markers in prostate cancer II: Diagnostic and prognostic cellular biomarkers. Acta Oncologica 2011; 50 (Suppl. 1): 76-84.

W dniach 27-28 czerwca 2014 r. odbędzie się w Gdańsku trzynaste „Spotkanie Po ASCO”

\author{
Organizatorzy: \\ Oddział Gdański Polskiego Towarzystwa Onkologicznego \\ Stowarzyszenie "Gdańskiej Onkologii" \\ Polskie Towarzystwo Onkologii Klinicznej
}

Celem konferencji jest przedstawienie najciekawszych doniesień z konferencji ASCO 2014, które odbędzie się w Chicago w dniach 30 maja-3 czerwca 2014 r.

Miejsce:

Polska Filharmonia Bałtycka w Gdańsku

Liczba uczestników jest ograniczona, o kwalifikacji decyduje kolejność zgłoszeń.

W ramach opłaty zjazdowej zapewniamy materiały zjazdowe, posiłki oraz udział w spotkaniu towarzyskim.

Zgłoszenia można dokonać wyłącznie poprzez stronę internetową www.poasco.pl.

Informacje:

ul. Sobieskiego 64/2, 80-216 Gdańsk

tel.: 5834047 25, faks: 583404727

e-mail: biuro@poasco.pl 